\title{
Communication and antithesis in corporate annual reports: a research note
}

\author{
by \\ Jane Davison ${ }^{0}$
}

March 2002

\begin{abstract}
The paper aims to identify one of the communication techniques which creative designers may use in the Annual Review/Annual Report and Accounts, described by Hopwood (1996) as a 'largely unresearched document'. It offers a new dimension to add to existing work on graphs, accounting narratives, readability and visual images by Armenic \& Craig (2000), Beattie \& Jones (1992, 1994, 1996, 1997, 1999, 2000), Courtis (1995, 1998), Graves et al (1996), McKinstry (1996), Preston et al (1996), Walters-York (1996). Using analytical methods from within artistic disciplines, the paper examines the use of antithesis in structure, visual material and text of Reuters 2000 Annual Review and Report and Accounts. It is suggested that the framing and communicative power of such techniques may supplement the accounting disclosures. Further possible applications and lines of enquiry are outlined.
\end{abstract}

Keywords: Communication, Rhetoric, Antithesis, Annual reports, Narrative, Visual

\footnotetext{
Jane Davison is a lecturer in accounting at Brunel University, UK, and a chartered accountant (ICAEW) with City of London auditing experience within a major firm. She has also conducted research in the field of contemporary French literature.

Address for correspondence: Jane Davison, Department of Economics and Finance, Brunel University, Uxbridge UB8 3PH, UK. Tel:0044 1895 203173. Email:jane.davison@ brunel.ac.uk.

I am grateful to the Institute of Chartered Accountants of Scotland for a grant to undertake this research, and to Vivien Beattie, John Courtis, Chris Mallin, Len Skerratt and two independent reviewers for insightful comments.
} 


\section{INTRODUCTION}

'The Annual Report and Accounts is a largely unresearched document' are Anthony Hopwood's introductory words to the 1996 special issue of Accounting, Organizations and Society devoted to visual images and the corporate annual report. He goes on to refer to the lack of attention that research has given to 'the wider influences on the document within which the accounting components are embedded', given the way in which the Annual Report of recent years demonstrates 'a more active management of the corporate image', 'a more proactive construction of a quite particular visibility and meaning' (Hopwood, 1996).

This current study aims to add a new dimension to understanding of the nonaccounting elements of annual reports by applying fresh analytical methods from artistic disciplines to identify techniques of communication which creative designers may use in the material that accompanies, and frames, the statutory accounting information. The technique chosen for illumination is the figure of antithesis, one of many rhetorical devices which may be used with great effect not simply to embellish, but also to influence or even engender patterns of reading and thinking in the user of corporate annual reports.

The paper is divided into two parts: (1) The first section considers implications for the accountancy profession of the messages conveyed by the creative design material in corporate annual reports. (2) The second section analyses such material in one annual report. It highlights the use of the rhetorical device of antithesis in a detailed case study of structure, visual material and text in Reuters 2000 Annual Report and Accounts. It finds that the reception of Reuters 2000 results has been placed in a dual 
context, which presents Reuters' long history and reputation alongside current corporate activities.

\section{IMPLICATIONS FOR THE ACCOUNTANCY PROFESSION}

\section{Framing and communicative power}

The establishment of communication paths, evidenced by the following case study, firstly towards the creative design material, and then within the design material, may be seen as a manifestation of the 'framing' effect identified by Tversky and Kahneman (1986), - 'the framing of decisions depends on the language of presentation, on the context of choice, and on the nature of the display'. 'Framing is controlled by the manner in which the choice problem is presented as well as by norms, habits, and expectancies of the decision maker'. As indicated in the case study of Reuters, the messages communicated by creative design are frequently more compelling than those of the financial statements.

\section{Readership}

While accountants have formulated an ever more intricate structure of statements and standards, research has shown that both lay and expert readers are looking beyond the accounting numbers for enlightenment. Bartlett and Chandler's study into private shareholder readership of the corporate report (1997) finds 'a marked decline in the general readership of the balance sheet and the profit and loss account' while 'the narrative sections of the report seem to attract wider readership'. A more recent paper on analysts' use of earnings (Barker, 2000) finds, among other conclusions, that 
'earnings (and accounting data generally) play only a limited role in the analysts' information environment'.

\section{Regulatory implications}

A growing number of companies have over recent years voluntarily chosen to produce for shareholders, as is permitted by law, an Annual Review document which carries the bulk of the creative design material. In response to user surveys and articles which have indicated a desire for less, and simpler information, an increasing number of shareholders do not receive the full statutory accounting information. Although the Annual Review may reproduce regulated elements of the Annual Report and Accounts on a selective and voluntary basis, sections of the Annual Review largely fall outside the scope of regulation; the document therefore has an ambiguous status.

\section{Shortcomings of the accounting framework}

As the business world has become more complex, the accounting profession has found it difficult to keep pace with the growing importance of accounting for intangible assets, or the increasing demand for accounting to reflect social and environmental concerns. The annual report presents directors with the multiple challenges of the presentation of historical results together with the promotion of brand, and the reinforcement of shareholder value, as well as indicating corporate responsibility to the wider community. It would seem that the explosion of the persuasive efforts of creative design within corporate reporting marks a failure of both communication and substance of the financial statements themselves. 
The following case study analyses in detail the creative design material of one recent annual report, and in particular its use of antithesis. It finds that presentational opposites frame the reader's understanding of Reuters' business as a fusion of: old and new; blue chip plc and internet company; continuity and change; bases in Europe and America.

\section{ANTITHESIS IN REUTERS 2000 ANNUAL REVIEW/REPORT AND ACCOUNTS}

Any study of communication should be informed by tools of analysis developed within the fine arts, since the prime function of literature, music, or painting is to communicate. Common to all art forms is the use of a battery of rhetorical devices rhetoric in its broad sense, meaning the art of persuasion, evolved from the beginnings of philosophy and artistic communication, and codified in classical times. .

Antithesis is an ancient aesthetic pattern, common to all the arts, and said to be one of the most stable figures of rhetoric (Barthes, 1970). Furthermore, as Saussurian linguistics has shown, antithesis is central to the workings of the mind and the systems of opposition inherent in thought and language. In the words of Roland Barthes, antithesis is not just a figure of emphasis, a decoration of thought, but a means of propelling sense from an opposition of terms (Barthes, $1953 \& 1972$ ) ${ }_{\text {iii. }}^{\text {F For }}$ example,

\footnotetext{
'A time to be born, and a time to die; a time to plant, and a time to pluck up that which is planted;

A time to kill, and a time to heal; a time to break down, and a time to build up;

A time to weep, and a time to laugh; a time to mourn, and a time to dance;

Ecclesiastes 3
} 
It was the best of times, it was the worst of times, it was the age of wisdom, it was the age of foolishness, it was the epoch of belief, it was the epoch of incredulity, it was the season of Light, it was the season of Darkness, it was the spring of hope, it was the winter of despair, we had everything before us, we had nothing before us, we were all going direct to heaven, we were all going direct the other way'

Dickens, A Tale of Two Cities, opening lines

Antithesis, or contrast, is similarly employed by artists in the visual domain, making play between contrasting colours, shapes, light as well as content. For example, in $19^{\text {th }}$ century representational art, Hogarth engraves a contrasting pair, Gin Lane and Beer Street, the better to make a moral point, or in $20^{\text {th }}$ century abstract painting Kandinsky opposes circles and squares, large and small in his abstract painting Counterweights.

The case study presented here explores in detail the way in which the rhetorical device of antithesis is the prism through which the corporate image of Reuters is projected in its 2000 Annual Review/ Report and Accounts. Reuters makes an interesting choice as Reuters' own foundation is within the media; Reuters is known for producing design award winning annual reports.

The study is divided into three parts, which analyse structural antithesis, visual antithesis and textual antithesis, and reveal the omnipresence of opposites in presentation and message. While the financial statements necessarily focus on recent developments, the accompanying material permits the framing of current activities in a dual context which simultaneously impresses upon the reader the importance of Reuters' long history and reputation. 


\section{Structural antithesis}

For the year 2000 Reuters presents its results for the first time in an Annual Review document produced as a pair together with its Annual Report and Accounts.

\section{Insert Plate 1. Front cover.}

Antithesis, or contrast is already in evidence in the two booklets, presented in a double wallet, with identical covers, the full Annual Report in black and white, the Annual Review in colour. In common with a trend in the reporting format of many companies, the Report is weighty and contains the full statutory accounting data and information, while the Review contains a slimmer version of the statutory information preceded by a section of more easily assimilated visual and textual material.

The cover is itself arranged structurally in contrasting halves. The front cover is divided into two equal parts horizontally, the top half presenting a pair of bespectacled eyes from an old-fashioned drawing, the bottom half a pair of eyes unseen behind reflective glasses, from a contemporary photograph. The back cover is also formed of two halves which mirror each other, the top half here revealing that the visible eyes of the front cover belong to the 1873 portrait of Paul Julius Reuter, the founding chairman. Thus the very new has been placed alongside the wellestablished.

The first few pages of the Annual Review are similarly constructed around effects of symmetry. Pages 4, 6 and 8 are again divided into two halves, the top half depicting a key moment of achievement in Reuters' past, the bottom half a key moment in current 
affairs. In each case the past image is in black and white, the current image in colour. Again, pages 12 to 22 contrast freestanding images from Reuters' history with framed photos of Reuters at work in the present.

Thus, by cover and appearance alone, two contrasting communication paths have been established for the reception of the company's results. The lay reader, or the expert reader in a hurry, is likely to have been attracted to the Annual Review document in preference to the Annual Report and Accounts. Through the communication paths further established by structural patterns it is likely that many readers have been made receptive to a picture of a company with a solid history combined with an active present.

\section{Visual antithesis}

The structural antithesis described above may be further analysed in the visual material presented as part of the Annual Review document.

The front cover is divided into two parts, as mentioned above, representing the eyes of the face of historical Reuters, and the reflective glasses of an anonymous present. It is interesting in itself that the image chosen is that of the face, the hub of human communication, and within the face the eyes, themselves a pair, and perhaps the most potent symbol of communication. Each pair of eyes wears spectacles, binary and symbolic again, perhaps of magnification and clearer focus. 
The image of a pair of eyes is widely used in modern day publicity material, and could appear a tired symbol, accompanied by the equally hackneyed 'focus and vision' of the tickertape text in the centre. However, the Reuters cover makes imaginative use of the symbol in its depiction of two contrasting pairs of eyes.

The upper pair of eyes, an enlarged detail, belongs to a middle-aged man with a furrowed brow who has a still, steady and almost timeless gaze, framed by fine metal spectacles with clear lenses. The full portrait and caption which is part of the illustration of the back cover provides the added information that the eyes are those of Paul Julius Reuter, founding chairman of Reuters, painted in 1873. A European establishment and fully identified individual figure, with abundant side-whiskers and moustache, dressed in formal $19^{\text {th }}$ century style, conveys an impression of maturity, continuity and history.

In complete contrast, the lower pair of eyes, an enlarged detail again, but for which no full face picture is given, belongs to a smooth-faced young policeman. The photograph tells nothing of his gaze, hidden behind reflective spectacles. However, the reflections in the lenses do tell what the policeman can see, namely 'Bush and Gore supporters outside the US Supreme Court as they await the Supreme Court's decision on the US presidential election. December 2000'. Thus, an unknown American whose personal identity is unrevealed, wearing fashionable modern spectacles, reflecting movement, even uproar, at a critical moment in contemporary affairs, and a moment which will mould the future, conveys a message of modernity, youthfulness, change, uncertainty and perhaps disorder. 
The contrasting themes sketched in minimalist terms on the front cover are reinforced in three sets of contrasting photographs and other images presented in similar form in the opening pages.

\section{Insert Plate 2. 'Content'}

The first pair, against the caption 'content', devotes the upper half of the page to the Reuters-relayed headlines announcing the assassination of President Lincoln, presented in the 1865 typeface. The lower half of the page is a photograph depicting 'opposition supporters kissing while wearing gas masks after clashes with riot police outside the Yugoslav federal parliament in October 2000'. Again, there is duality and contrast in the presentation of two supporters. Again, the theme of communication is paramount, as they 'kiss' with the nozzles of gas masks, and two faces are centre stage, their eyes focal points through the glass.

Once more, America and Europe are set in opposition, as is stillness in the headlines contrasted with movement in the photograph, the $19^{\text {th }}$ century with $20^{\text {th }}$ century current affairs. However, here there is disorder in the content of both images, and a presentational shift inasmuch as on this page news of America is presented in antique monochrome, contrasted with news from Europe in modern colour photography.

\section{Insert Plate 3. 'Technology'}

The second pair of images, against the caption 'technology', contrasts a black and white photograph of Yuri Gagarin in spacesuit during the first manned space flight, 
when radio monitoring gave Reuters a 'two-minute beat' in London, with a colour photograph of a planetary nebula taken through the American Hubble Space Telescope. In the photograph of Yuri Gagarin a face, with upward gaze, is again the focal point, and again the face is surrounded by a protective screen in the form of the space helmet. While Yuri Gagarin presents a human image of calm contemplation, the planetary nebula is a kaleidoscopic, colourful and almost abstract picture of fire and movement, reminiscent of the millennium firework illustration Reuters used for the front cover of its 1999 Annual Report and Accounts. While Yuri Gagarin's space flight is a historic moment of the twentieth century, and already considered outmoded technology, the photograph of the nebula is taken using the most up-to-date technology, but of an event in space which took place several thousand years ago.

Thus, America and Europe are again set in opposition, as is continuity against change and movement, the very old and the very new. Again there is a shift in the message, in that the twentieth century is now presented as history, while one of the most ancient images known to man is presented as knowledge of the future.

\section{Insert Plate 4. 'Connectivity'}

The final pair of images, against the caption 'connectivity', contrasts a black and white etching dated 1850 from the Illustrated London News Picture Library, of a steamer laying electric submarine cable between Dover and Calais, a cable used by Reuters, with a modern colour photograph of a Reuters photographer at work at a 1998 World Cup football match in France. The steamer is travelling in a stormy sea, and there is movement everywhere, from the men at work to the back-cloth of clouds, 
flags, drifting smoke, bobbing buoys and turbulent waves. The football stadium is a calmer scene, the reader's attention taken by the face of the cameraman using the latest technology, such that his attention is directed not towards the camera itself, but the computer equipment which controls the pictures for transmission across the internet.

While both of these images are European, the previous oppositions of history and modernity, movement and calm are again apparent, but with further displacement: now movement and perhaps turmoil is a characteristic of the past, and a controlled image a representation of the present.

The smaller and less striking images of the inner pages contrast a wealth of historical detail against pictures of Reuters at work today. For example, an 1865 Morse receiver, a full height cartoon of Paul Julius Reuter, a photograph of Reuters' headquarters in Fleet Street in 1951, a message sent by hot-air balloon in 1870, old photographs of Reuters messenger boys and girls, further emphasise the themes of communication, history and European tradition contrasted with images of modern-day internet technology. Interestingly, Reuters' acquisition of the e-broking company, Instinet, is represented as an antique-look bound leather volume of documents.

The antithetical communication paths of the structure have been fleshed out in the contrasting themes apparent in the visual material. The reader is likely by now to have absorbed opposing but interwoven and fused messages, where key strands are Europe and America, tradition and modernity, continuity and change. The reader has 
absorbed these dual messages through an abundance of images of vehicles of communication, as befits a business based in media and information technology.

\section{Textual antithesis}

Turning to the textual narrative that accompanies the visual material, this may be examined for evidence of further reinforcement of the antithetical messages carried in the illustrations.

The first words presented to the reader are in the form of a representation of a thread of computerised ticker-tape, symbolic of Reuters' business, which runs horizontally across the centre of the front cover and further key pages, injecting a sense of movement and real-time.

Where the front cover carries

'Focus and vision for 150 years.....',

the back cover carries

'Now and always, an innovator.....'.

Thus the contrasting themes of the visual material are strengthened in the language, as Reuters' long history is set against its state-of-the-art expertise. 'Focus and vision' in 
the text complements the many pairs of eyes and spectacles noted to be present in the illustrations.

The first significant section of text is to be found on the inside cover:

\author{
'REUTERS MARKS ITS $150^{\mathrm{TH}}$ ANNIVERSARY IN 2001. THOUGH THE WORLD HAS \\ CHANGED, OUR FOCUS HAS NOT. WE ARE AN AGENT OF CHANGE, USING \\ THE LATEST MEANS OF COMMUNICATION TO INFORM AND CONNECT OUR \\ CUSTOMERS. IN 1850 PAUL JULIUS REUTER USED PIGEONS TO FLY STOCK \\ MARKET PRICES BETWEEN BRUSSELS AND AACHEN, BRIDGING A GAP IN \\ THE EUROPEAN TELEGRAPH SYSTEM. THE FOLLOWING YEAR HE MOVED \\ TO LONDON TO TRANSMIT NEWS AND PRICES TO EUROPE VIA THE NEWLY OPENED \\ DOVER-CALAIS SUBMARINE CABLE.
}

TODAY, WE USE INTERNET-BASED TECHNOLOGIES TO SATISFY THE WORLD'S GROWING DEMAND FOR INFORMATION. OUR BLEND OF CONTENT, TECHNOLOGY AND CONNECTIVITY IS UNIQUE. WE USE THIS WINNING COMBINATION TO SERVE CUSTOMERS AND, IN SO DOING, TO CREATE VALUE FOR SHAREHOLDERS.

Here, similar techniques of contrast may be found to be employed, articulating a comparable message. Again, the text is structured in two opposing sections. The first paragraph concentrates on the colour of Reuters' $19^{\text {th }}$ century European history, in itself referring to bridges between different places, and provides concrete examples: a named individual (Paul Julius Reuter), named places (Europe, Brussels, Aachen, London, Dover, Calais), concrete means of communication (pigeons, telegraph, submarine cable), defined objects of communication (stock-market prices, news and prices). The second paragraph, on the other hand, referring to the present-day, is more abstract and general, as perhaps befits modern-day globalisation and internet communication: the only named place is 'the world', the means of communication 'internet-based technology', the objects of communication 'information', 'content'.

It is of particular interest that antithesis is again specifically articulated: 
'Though the world has changed, our focus has not',

and the use of the words 'blend' and 'combination' directly sow the seed of the idea of fusion.

'The year 2000 was as good for Reuters as 1999 was difficult'

are the opening words of the Chairman's Statement, framed in antithetical terms.

Later, in the third paragraph:

'It required a major effort in 2000 to assess Reuters' momentum between the opposite poles of continuity and change'

articulates quite clearly and graphically both the concept of antithesis, and its expression in Reuters' Annual Review document as the poles of 'continuity' and 'change' previously analysed in the illustrations. Scattered through the Chairman's Statement is a vocabulary of continuity and solidity ('foundations', 'well laid', 'intact', 'plans', 'anticipated', 'preparations', ‘continuing', 'preservation', 'core' twice, 'strengthening', 'embodied', 'trust', 'touchstone', 'security', 'safeguarded'), contrasted with a lesser vocabulary of change ('transformation', 'formidable scale', 'long way to go', 'burgeoning').

\section{Summary}


In the case of Reuters 2000 Annual Review and Report and Accounts, antithesis has proved an illuminating tool of analysis. It has been shown that Reuters has framed the reception of its 2000 results in an antithetical design apparent in structure, visual and textual material, which provides a broader context by combining moments from corporate and world history with news of corporate developments and current affairs. Strands of old and new, blue chip plc and internet company, stability and change, Europe and America are set in opposition, interwoven and displaced relative to each other. By these effects of displacement, the duality of context is subtle and shifting: 'new' moves from association with America to association with Europe; 'new' becomes history and vice versa; 'stability' moves from being presented as a characteristic of the past to an image of the present.

\section{CONCLUSIONS}

This paper's contribution has been firstly to outline implications for the accountancy profession of the creative design material which frames the reception of annual financial statements; secondly to widen exploration of a range of connections between annual reports and artistic disciplines by introducing the rhetorical device of antithesis; and thirdly to offer a full explication de texte of one annual review document, demonstrating that the use of an ancient device has facilitated communication of a dual understanding of Reuters' business.

The use of such devices is likely to be widespread in the creative design material of corporate annual reports. The cost of the design material is small compared to that of the financial statements, and its impact is greater in its persuasive powers, its breadth and depth of subject-matter and its readership. It currently falls largely outside the 
scope of regulation - should it be regulated? Can it be regulated other than by being eliminated? Or does creative design enhance communication, complement the accounting numbers and provide valuable insight into a company's business and individuality?

Further lines of enquiry suggest themselves. A variety of rhetorical devices could be analysed across larger samples of annual reviews and reports. Beyond rhetorical devices, all manner of theories or intuitions of communication evolved within literary and linguistic studies are likely to be invaluable in elucidating the techniques at work, sometimes consciously, sometimes perhaps unconsciously, in the pages of corporate annual reviews and reports.

\footnotetext{
${ }^{\mathrm{i}}$ A brief survey of existing academic literature on accounting narratives and associated visual material indicates a small but expanding field. Lee contributed a historical review and quantification of the changing form of the annual report, now in need of updating. Work on accounting narratives by Aerts, Courtis, Jones, Shoemaker, Smith and Taffler and Sydserff and Weetman has examined causal reasoning patterns, attributional content or readability with the aid of statistical techniques and reader surveys. Brennan and Gray analyse rhetoric and argument in profit forecasts and take-over documents, rhetoric very loosely defined as the art of persuasion. Armenic, Armenic and Craig and Walters-York have examined the rhetorical device of metaphor in accounting. There is a strong corpus of work on graphs by Beattie and Jones. Work on other visual content in annual reports includes three interesting papers in the special issue of Accounting, Organisations and Society. Full references are available on request.

${ }^{\text {ii }}$ For a good exposition of rhetoric see Walters-York (1996)

iii ' $L$ 'antithèse n'est pas seulement une figure emphatique, c'est-à-dire en somme un simple décor de la pensée; c'est probablement autre chose et plus; une façon de faire surgir le sens d'une opposition de termes'.
}

\section{References}

Barker, R. (2000), "FRS3 and analysts' use of earnings", Accounting and Business Research, Vol. 30 No. 2, pp. 95-109

Barthes, R. (1953 \& 1972), "La Rochefoucauld: 'Réflexions ou Sentences et Maximes", Le degré zéro de l'écriture, Le Seuil, Paris, pp. 69-88

Barthes, R. (1970), “L’Antithèse I: le supplément”, S/Z, Le Seuil, Paris, pp. 33-35

Barthes, R. (1982), “Rhétorique de l'image', L'obvie et l'obtus, Le Seuil, Paris, pp. $25-42$ 
Barthes, R. (1985), “L'Ancienne Rhétorique”, L'aventure sémiologique, Le Seuil, Paris, pp. 85-165

Bartlett, S. A. And Chandler, R. A. (1997), "The corporate report and the private shareholder: Lee and Tweedie twenty years on", British Accounting Review, Vol. 29, pp. 245-261

Dickens, C. (1859), A Tale of Two Cities

Hopwood, A. (1996), "Making visible and the construction of visibilities: shifting agendas in the design of the corporate report: introduction, Accounting, Organizations and Society, Vol. 21 No. 1, pp. 55-56

Tversky, A. and Kahneman, D. (1986), "Rational Choice and the Framing of Decisions", Journal of Business, Vol. 59, Issue 4, Part 2: The Behavioral Foundations of Economic Theory, pp. 251-278

Walters-York, L. M. (1996) "Metaphor in accounting discourse", Accounting, Auditing and Accountability Journal, Vol. 9 No. 5, pp. 45-70 